\title{
Insect resistance and risk assessment studies of advanced generations of basmati rice expressing two genes of Bacillus thuringiensis
}

\author{
Mahmood-ur-Rahman \\ National Center of Excellence in Molecular Biology \\ 87-W, Canal Bank Road \\ University of The Punjab \\ Lahore, Pakistan \\ Tel: 92425423942 45. Ext. 327 \\ Fax: 92425421316 \\ E-mail: mahmood1233@yahoo.com

\section{Hamza Rashid} \\ National Center of Excellence in Molecular Biology \\ 87-W, Canal Bank Road \\ University of The Punjab \\ Lahore, Pakistan \\ Tel: 92425423942 45. Ext. 327 \\ Fax: 92425421316 \\ E-mail: hamza1@yahoo.com
}

\author{
Ahmad Ali Shahid \\ National Center of Excellence in Molecular Biology \\ 87-W, Canal Bank Road \\ University of The Punjab \\ Lahore, Pakistan \\ Tel: 92425423942 45. Ext. 327 \\ Fax: 92425421316 \\ E-mail: aali@cemb.edu.pk

\section{Khurram Bashir} \\ Laboratory of Plant Biotechnology \\ Department of Global Agricultural Scienses \\ 1-1-1, Yayoi, Bunkyo-ku \\ Tokyo 113-8657, Japan \\ Tel:81 8050693749 \\ E-mail: bashirkhurram@yahoo.com
}

\section{Tayyab Husnain*}

National Center of Excellence in Molecular Biology

87-W, Canal Bank Road

University of The Punjab

Lahore, Pakistan

Tel: 92425423942 45. Ext 334

Fax: 92425421316

E-mail: tayyab@cemb.edu.pk

\section{Sheikh Riazuddin}

National Center of Excellence in Molecular Biology

87-W, Canal Bank Road

University of The Punjab

Lahore, Pakistan

Tel: 92425421350

Fax: 92425421316

E-mail: riaz@lhr.comsats.net.pk

Financial support: Grants from Ministry of Science and Technology and Higher Education Commission of the Government of Pakistan.

Keywords: bio-safety, $\operatorname{cry} 1 A c, \operatorname{cry} 2 A$, gene flow, field trials, gene pyramiding, insect resistance.

*Corresponding author 

Abbreviations:
RLF: Rice Leaf Folder
RCBD: Randomized Complete Block Design
YSB: Yellow Stem Borer

\begin{abstract}
Advanced generations of different transgenic lines of indica basmati rice (Basmati-370) expressing two unrelated $B t$ genes, $c r y 1 A c$ and $c r y 2 A$ were evaluated for resistance to Yellow Stem Borer (YSB) and Rice Leaf Folder (RLF) under field conditions compared to control lines over three years (2003-2005). Homozygous lines were selected and analyzed for insect resistance, morphological, physiochemical properties and risk assessment studies. After artificial infestation of target insects, the transgenic plants showed significant resistance. Data were recorded in terms of dead hearts and white heads at vegetative and flowering stage respectively. Transgenic lines showed up to 100 and $\mathbf{9 6 \%}$ resistance against yellow stem borer at vegetative and flowering stages, respectively. Natural damage of rice leaf folder was also observed during the year 2005. The transgenic plants were $98 \%$ more resistant as compared to untransformed control plants. Variations in some morphological characteristics, e.g., the average number of tillers, plant height and maturity were also observed. Transgenic lines produced $40 \%$ more grains than control plants. All these characteristics were stably inherited in advanced generations. The transgenic lines had no significant effect on non-target insects (insects belonging to orders other than Lepidoptera and Diptera) in field or under storage conditions. Chances of pollen-mediated gene flow were recorded at a rate of $0.14 \%$.
\end{abstract}

Rice (Oryza sativa L.) is one of the world's most important crops, providing a staple food for nearly half of the global population (FAO, 2004). Almost $90 \%$ of the rice is grown and consumed in Asia (Khush and Brar, 2002). It feeds more than two billion people in the developing countries of Asia (FAO, 1995). Basmati rice varieties of Indo-Pak subcontinent are economically important due to high quality, distinguished long grain and aroma. However its production is lower than other varietal groups, as it is more susceptible to insect damage (Khan et al. 1991).

The most destructive insect pests of the rice crop are Yellow Stem Borer (YSB; Scirpophaga incertulas Walk.) and Rice Leaf Folder (RLF; Cnaphalocrocus medinalis). Globally, YSB alone causes yield losses of 10 million tons and accounts for $50 \%$ of all insecticides used in rice field (Huesing and English, 2004). YSB attacks the crop from the seedling up to the harvesting stage and thus causes complete loss of affected tillers (Salim and Masih, 1987). Dead heart is produced when the insect attacks at vegetative stage while white head occurs when the stem borers attack at the time of ear development. Larvae of RLF fold the tip of the leaf over itself as a shield against the environment. It eats the green parts of the leaf until only the skeletal white parts are left. Moreover, the infected plants are predisposed to bacterial and fungal infection (Bashir et al. 2004a).

The most significant breakthrough in plant biotechnology is the development of the techniques to transform genes from unrelated sources into commercially important crop plants to develop resistance against insect pests (Lycett and Grierson, 1990; Dhaliwal et al. 1998). Bacillus thuringiensis $(B t)$ is perhaps, the most important source of insect resistant genes. Genes from $B$. thuringiensis encode for crystal proteins, which are toxic against larvae of different insects, e.g. Lepidopterans (Whiteley and Schnepf, 1986; Höfte and Whiteley, 1989; Cohen et al. 2000), Coleopterans (Krieg et al. 1983; Herrnstadt et al. 1986) and Dipteran insects (Andrews et al. 1987). These genes are generally safe for human consumption (BANR, 2000).

Some groups have transformed rice with $B t$ genes and evaluated their effectiveness under greenhouse conditions (Cheng et al. 1998) as well as in the field (Shu et al. 2000; Ye et al. 2001a; Ye et al. 2001b; Ye et al. 2003; Bashir et al. 2004a; Breitler et al. 2004; Bashir et al. 2005). Most of the transgenic lines used in field trials expressed $c r y 1 A b$, crylAc, $\operatorname{cry} 2 A$ or a fused gene from crylAb/crylAc. Although these lines provide high level of resistance against lepidopteran insects, however $B t$ cultivars have the same weaknesses as many other technologies to control insects e.g. insects can evolve resistance to them eliminating their effectiveness. More than 500 species of

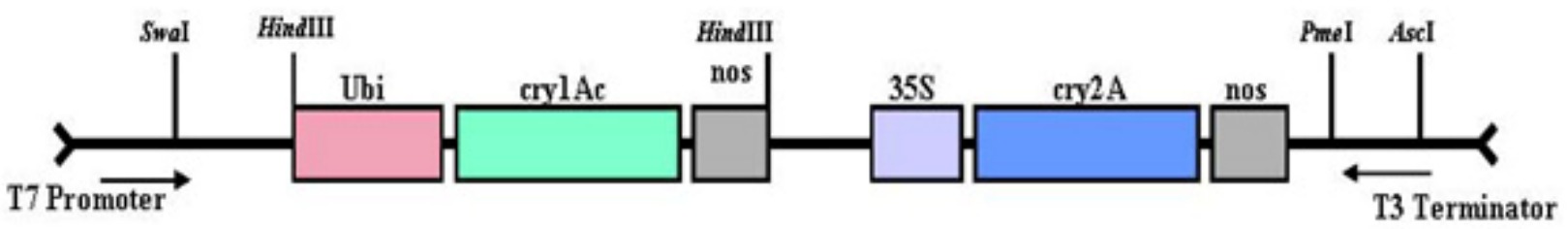

Figure 1. Construct map of pSM6 containing cry1Ac and cry2A transgenes. 
Table 1. The percent damage of target and non-target insect pests to transgenic and control rice.

\begin{tabular}{|c|c|c|c|c|c|}
\hline \multirow{2}{*}{ S. No. } & \multirow{2}{*}{ Insect damaged } & \multicolumn{3}{|c|}{ Year-wise percent insect damage } & \multirow{2}{*}{ Control (\%) } \\
\hline & & 2003 & 2004 & 2005 & \\
\hline 1. & $\begin{array}{l}\text { Damage of YSB } \\
\text { (a) at vegetative stage* } \\
\text { (b) at flowering stage }{ }^{* *}\end{array}$ & $\begin{array}{l}2.42^{b} \\
0.26^{b}\end{array}$ & $\begin{array}{l}3.61^{b} \\
1.94^{b}\end{array}$ & $\begin{array}{l}3.42^{b} \\
0.00^{b}\end{array}$ & $\begin{array}{l}100^{\mathrm{a}} \\
100^{\mathrm{a}}\end{array}$ \\
\hline 2. & Damage of RLF & ND & ND & $0.83^{b}$ & $100^{a}$ \\
\hline 3. & Damage of storage insects & ND & ND & $83.0^{\mathrm{NS}}$ & $100^{a}$ \\
\hline 4. & Damage of non-target insect & $5.00^{\mathrm{NS}}$ & $6.3^{\mathrm{NS}}$ & $6.1^{\mathrm{NS}}$ & $5.9^{\mathrm{NS}}$ \\
\hline
\end{tabular}

Note: Values with the same letters are not significantly different from each other according to LSD test at $5 \%$ level of significance. $\mathrm{ND}=$ Not Determined.

${ }^{*}$ Dead hearts were counted and expressed as percent of the total tillers.

${ }^{* *}$ White heads were counted and expressed as percent of the total tillers.

insects have evolved resistance to conventional insecticides. So far, the track record of $B t$ is better. In the field, only one pest, the diamondback moth has evolved resistance to $B t$ sprays and none has evolved resistance to $B t$ crops (Ferré and Van Rie, 2002).

To prolong the resistance development time against $B t$ crops, it was recommended that only the lines expressing two $B t$ genes should be released into environment (Cohen et al. 2000). It was also strongly recommended that any two $B t$ toxins that are used in combination must not be too similar to each other, otherwise a single mutation could confer cross-resistance to both toxins. More than $100 \mathrm{Bt}$ genes have been cloned and sequenced and are found to be highly divergent in amino acid sequence and some biochemical properties (Frutos et al. 1999). Studies showed that Cry1Ac with Cry2A is good toxin combination for lepidopteran insects (Fiuza et al. 1996).

A variety of issues in addition to development of resistance by target pest species, such as horizontal gene transfer, impact on non-target invertebrates, and morphological as well as agronomic performance must be considered when developing insect-resistant transgenic plants. In addition to gene pyramiding described above, the possibility of target insects evolving resistance towards transgenic plants could also be mitigated through the use of a high dose/refugia strategy. Not all popular cultivars should be transformed with $B t$ genes in order to maintain refugia (Cohen et al. 2000). It is also important to check if advanced generations of these lines are also resistant to insects in the field or if they lose their effectiveness with the passage of time which could result in accelerated development of resistance in the target pests. The chances of pollen-mediated gene flow from these lines to wild relatives and other commercial cultivars are also important to consider. The response to non-target insects to these transgenic plants (e.g. Bashir et al. 2004a; Bashir et al. 2004b) is also important, both for herbivorous insects which may result in secondary pest outbreaks and beneficial invertebrates.

Morphological characteristics and agronomic performance of transgenic crops are also of utmost importance when developing a commercially viable cultivar. Morphological variation has already been reported for rice transformed by PEG or protoplast electroporation (Jiang et al. 2000) in agrobacterium and particle mediated transformation. So, there should not be any compromise for morphological/agronomic traits like average no. of tillers per plant, average plant height, days to maturity and yield during selection of desirable lines.

The present studies were conducted at the National Center of Excellence in Molecular Biology, Lahore, Pakistan (CEMB) as well as at various other locations in Punjab, Pakistan and the performance of advanced generations of locally transformed lines of Basmati-370 was determined against YSB and RLF. Bio-safety aspects i.e. effects on non-target insects, horizontal and vertical gene flow and allelopathic effects were also studied.

\section{MATERIALS AND METHODS}

\section{Plant material and experimental design}

The seeds of Oryza sativa L. variety Basmati-370 were obtained from Rice Research Institute (RRI), Kala Shah $\mathrm{Kaku}$, Lahore, Pakistan. Seeds were cultured on MS medium supplemented with 2,4-D (2 $\left.\mathrm{mg} \mathrm{L}^{-1}\right)$, casein hydrolysate $\left(200 \mathrm{mg} \mathrm{L}^{-1}\right)$ and L-proline $\left(300 \mathrm{mg} \mathrm{L}^{-1}\right)$. One 


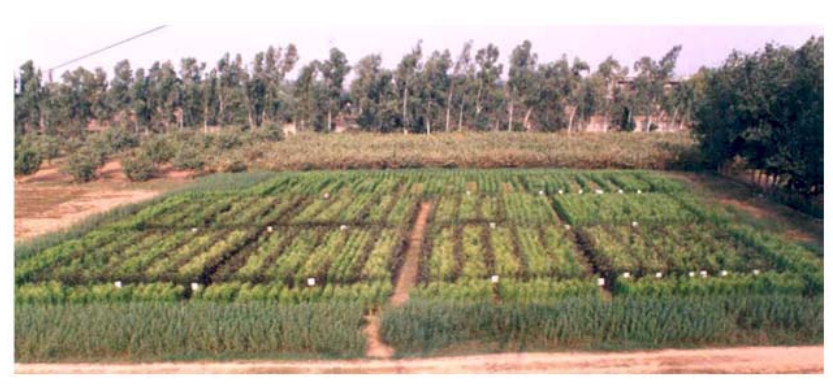

Figure 2. Lay out of the field. Transgenic rice along with its untransformed control grown under RCBD. Field surrounded by non-Bt refugia and Sesbenia canabena.

to two week old scutellum derived calli from mature seeds of rice were used for transformation experiments. Plasmid pSM6 carrying crylAc under the control of ubiquitin promoter and $c r y 2 A$ driven by $C a M V 35 S$ promoter were used in these studies (Figure 1). The transformation was done through particle bombardment method as described previously (Husnain et al. 1995; Husnain et al. 1997).

The sixth generation of three homozygous transgenic lines L-8-22-2, L-8-22-32 and L-8-22-35 were selected on the basis of insect resistance, agronomical and morphological performance under field conditions (Bashir et al. 2005). All these lines harbour two un-related $B t$ genes i.e. crylAc and $\operatorname{cry} 2 A$. These lines were sown under field conditions for three consecutive years (2003-2005) according to randomized complete block design (RCBD) with four replications of 700 plants per block (Figure 2).

Experimental fields were surrounded with rows of untransformed plants, to serve as refugia. Purple leaved variety (CP-1) was sown between transgenic lines to trap pollen grains and to determine the chances of gene flow from transgenic lines to other cultivars. Sesbania canabena was grown around the field to isolate the field from surroundings. All agronomic requirements were fulfilled and studies were carried out according to the recommendations and Biosafety guidelines (NBC, 1999).

\section{Insect infestation and data recording}

The Entomology Division of CEMB provided YSB larvae. Their moths were collected from different rice growing areas in Lahore, Pakistan. These moths were reared on rice plants covered by muslin cloths at $28 \pm 2^{\circ} \mathrm{C}, 60-70 \%$ relative humidity with a 14 hrs photo phase. The egg masses were collected and hatched in glass vials under the same conditions. The artificial infestation was done in three instalments, two at vegetative stage and one at flowering stage. Twenty neonate larvae were starved for $12 \mathrm{hrs}$, and then released on to each plant using camel hairbrush on all 175 plants. In this way, 10500 larvae of YSB were released in the field each year.

Although naturally, YSB damages the rice plants from seedling to harvest depending upon the environmental conditions, artificial infestations were done at critical stages of plant growth i.e., after tillering stage and at flowering stage. Natural infestations of YSB and RLF were observed during 2005. Leaf folder was not infested artificially and the data was recorded only for natural attack during the year 2005 .

Insect damage was recorded at 20 days after transplanting by counting dead hearts and white heads per plant and expressed as percentage of total tillers and panicles. The damage in untransformed control plants was expressed as $100 \%$ and the damage in different transgenic lines was expressed as percent damage in comparison with the untransformed control. To assess the damage caused by RLF, the number of infested leaves were counted and

Table 2. Comparison of morphological characteristics between transgenic and untransformed control basmati rice.

\begin{tabular}{|l|c|c|c|c|c|c|c|c|}
\hline Line No. & $\begin{array}{c}\text { No. of } \\
\text { tilles. }\end{array}$ & $\begin{array}{c}\text { Plant height } \\
\mathbf{( c m )}\end{array}$ & $\begin{array}{c}\text { Days for } \\
\text { panicle } \\
\text { initiation }\end{array}$ & $\begin{array}{c}\text { Days to } \\
\text { maturity }\end{array}$ & $\begin{array}{c}\text { Panicle } \\
\text { length (cm) }\end{array}$ & $\begin{array}{c}\text { Flag leaf } \\
\text { area (cm }\end{array}$ & $\begin{array}{c}\text { Average } \\
\text { yield (\%) }\end{array}$ & Awns \\
\hline L-8-22-2 & $25^{\mathrm{a}}$ & $109^{\mathrm{a}}$ & $83^{\mathrm{a}}$ & $104^{\mathrm{a}}$ & $27^{\mathrm{NS}}$ & $32^{\mathrm{NS}}$ & $140^{\mathrm{a}}$ & Absent \\
\hline L-8-22-32 & $23^{\mathrm{a}}$ & $105^{\mathrm{a}}$ & $85^{\mathrm{a}}$ & $106^{\mathrm{a}}$ & $26^{\mathrm{NS}}$ & $30^{\mathrm{NS}}$ & $140^{\mathrm{a}}$ & Absent \\
\hline L-8-22-35 & $24^{\mathrm{a}}$ & $111^{\mathrm{a}}$ & $83^{\mathrm{a}}$ & $104^{\mathrm{a}}$ & $29^{\mathrm{NS}}$ & $29^{\mathrm{NS}}$ & $140^{\mathrm{a}}$ & Absent \\
\hline Control & $17^{\mathrm{b}}$ & $156^{\mathrm{b}}$ & $104^{\mathrm{b}}$ & $131^{\mathrm{b}}$ & $28^{\mathrm{NS}}$ & $31^{\mathrm{NS}}$ & $100^{\mathrm{b}}$ & Present \\
\hline
\end{tabular}

Note: Numbers with the same letter within a column are not significantly different from each other according to LSD test at $5 \%$ level of significance. 
expressed as percentage of total leaves.

\section{Morphological and physiochemical characteristics}

Different morphological characters including average number of tillers, plant height, days for panicle initiation and days to maturity, panicle length, flag leaf area, presence and absence of awns and average yield were studied according to the standards described by the INGER (1996). The yield of the transgenic plants was calculated as a percent increase or decrease relative to control plants. Likewise, the percent differences in physiochemical characteristics like kernel length, kernel width, length to breadth ratio, and so forth, of transgenc plants were calaculated relative to control plants.

Biochemical analyses of transgenic seeds were undertaken to estimate the effect of transformation on different physiochemical properties of the rice. The average kernel length was determined with the help of vernier caliper and expressed in $\mathrm{mm}$. The length-breadth ratio was estimated by dividing the length by the breadth. One hundred seeds from different transgenic lines were soaked in water in duplicate for $30 \mathrm{~min}$ and then kept in boiling water for 20 min. After this treatment, the average length of randomly selected seeds was recorded and elongation percentage was calculated. Similarly the percentage of curling and bursting was also recorded.

Alkali spreading values were recorded after immersion of milled seeds in $1.7 \% \mathrm{KOH}$ at $30^{\circ} \mathrm{C}$ for $24 \mathrm{hrs}$ (Little et al. 1958). Values were recorded by comparing the dispersion in comparison to check samples of known behaviour. Apparent amylose content was estimated by the method described by Williams et al. (1958) and modified by Juliano (1971). The presence or absence of aroma from cooked seeds was confirmed by a team of three scientists according to the method described by Dong et al. (2000).

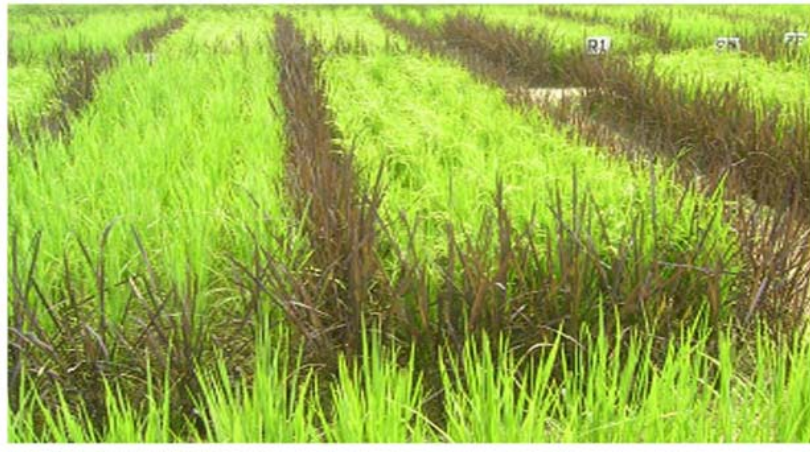

Figure 3. CP1 grown between transgenic lines of Basmati370 to estimate percent gene flow from transgenic to untransformed control variety.

\section{Risk assessment studies}

Solution extracted by soaking dry straw, @ 100g L $\mathrm{g}^{-1}$ of pure water, from all transgenic and control lines was used to check the allelopathic effects on germination of three local varieties of wheat. The seeds of the wheat varieties were kept on filter papers for germination, which were soaked with solution extracted from transgenic and control lines according to the Completely Randomized Design (CRD). The data were processed through analysis of variance followed by LSD at $5 \%$ to determine the difference between means.

Ten plants per plot were selected to study the extent of damage caused by different non-target insects. Firstly these insects were identified in the field and the damage caused by them was described, then the number of infected leaves per plant were counted and expressed as the percentage of the total leaves. One thousand seeds of stored rice were taken and the seeds damaged by red flour beetle (Tribolium castaneum Herbst.), a non-target insect, were counted. The

Table 3. Comparison of different physiochemical properties of transgenic basmati rice and control plants.

\begin{tabular}{|l|c|c|c|c|c|c|c|c|c|}
\hline Line No. & $\begin{array}{c}\text { Amylose } \\
(\%)\end{array}$ & $\begin{array}{c}\text { Alkali } \\
\text { spreading } \\
\text { value }\end{array}$ & $\begin{array}{c}\text { Av. grain } \\
\text { length } \\
(\mathbf{m m})\end{array}$ & $\begin{array}{c}\text { Av. grain } \\
\text { breadth } \\
(\mathbf{m m})\end{array}$ & $\begin{array}{c}\text { Length } \\
\text { breadth } \\
\text { ratio }\end{array}$ & $\begin{array}{c}\text { Bursting } \\
(\%)\end{array}$ & $\begin{array}{c}\text { Curling } \\
(\%)\end{array}$ & $\begin{array}{c}\text { Elongation } \\
\text { ratio }\end{array}$ & Aroma \\
\hline L-8-22-2 & $24.05^{\mathrm{NS}}$ & $4-5^{\mathrm{NS}}$ & $7.55^{\mathrm{NS}}$ & $1.95^{\mathrm{b}}$ & $3.8^{\mathrm{b}}$ & $6.1^{\mathrm{a}}$ & $8.8^{\mathrm{a}}$ & $1.38^{\mathrm{a}}$ & Present \\
\hline L-8-22-32 & $23.40^{\mathrm{NS}}$ & $4-5^{\mathrm{NS}}$ & $7.70^{\mathrm{NS}}$ & $2.19^{\mathrm{a}}$ & $3.5^{\mathrm{a}}$ & $9.4^{\mathrm{b}}$ & $6.8^{\mathrm{c}}$ & $1.25^{\mathrm{b}}$ & Present \\
\hline L-8-22-35 & $24.00^{\mathrm{NS}}$ & $4-5^{\mathrm{NS}}$ & $7.85^{\mathrm{NS}}$ & $1.96^{\mathrm{b}}$ & $3.9^{\mathrm{b}}$ & $9.8^{\mathrm{b}}$ & $8.1^{\mathrm{b}}$ & $1.22^{\mathrm{b}}$ & Present \\
\hline Control & $23.65^{\mathrm{NS}}$ & $4-5^{\mathrm{NS}}$ & $7.40^{\mathrm{NS}}$ & $1.75^{\mathrm{c}}$ & $3.7^{\mathrm{ab}}$ & $6.7^{\mathrm{c}}$ & $7.3^{\mathrm{c}}$ & $1.71^{\mathrm{c}}$ & Present \\
\hline
\end{tabular}

Note: Values followed by the same letter within a column are not significantly different from each other according to LSD at $5 \%$ level of significance. 
data were expressed in terms of percent damage as compared to $100 \%$ damage in seeds of the control plants. The presence and activities of predators and visiting insects were also observed in the field.

The Purple leaved line CP-1 was used as morphological marker to calculate the percent cross-pollination between transgenic lines and $\mathrm{CP}-1$. Two pairs of recessive genes control purple pigmentation in $\mathrm{CP}-1$ and at least one of them is inhibitory in action. This system can successfully be used as morphological marker to identify the hybrids (Mahalingam and Nadarajan, 2005). Plants of this line were sown between test lines (Figure 3). Progeny harvested from CP1 was studied for inheritance of leaf color and crosspollination was expressed in percentage (Figure 4). Seeds from CP-1 lines were harvested separately and in the next season were grown to identify hybrids.

The CP-1 seeds were obtained from Nuclear Institute for Agriculture and Biology (NIAB), Faisalabad, Pakistan. Plants of this line were sown between test lines and progeny harvested from CP-1 was studied for inheritance of leaf colour and cross-pollination was expressed in percentage. Artificial crosses were also attempted between L-8-22-2, L-8-22-32, L-8-22-35, CP1 and B-370 in all possible combinations.

\section{Statistical analysis}

The data for insect damage were calculated and expressed as $100 \%$ in control and the damage in different transgenic lines was demonstrated as percent damage in comparison with control. Data regarding damage by YSB and RLF, non-target insects and storage pests were analyzed through analysis of variance (ANOVA) and the differences among means of lines were determined by using LSD test at $5 \%$ level of significance.

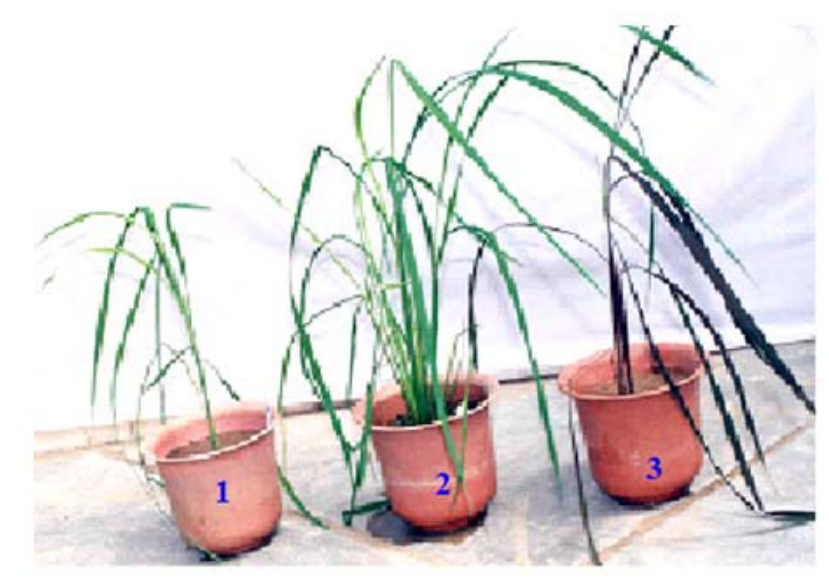

Figure 4. Identification of hybrid of CP1 and transgenic lines.

(1) Transgenic plant.

(2) Hybrid of CP1 and transgenic.

(3) CP1.
Morphological as well as physiochemical characteristics like average number of tillers, plant height, days to panicle initiation, days to maturity, panicle length, flag leaf area, yield, amylose contents, grain length and breadth, length to breadth ratio, elongation ratio, bursting and curling were subjected to analysis of variance (ANOVA) separately. The differences among means were examined using LSD test at $5 \%$ level of significance.

\section{RESULTS}

\section{Resistance against lepidopteron insects}

Twenty days after transplanting, the dead hearts observed in transgenic plants were $0.26,1.94$ and $0.0 \%$ as compared to untransformed plants during 2003, 2004 and 2005 respectively. All the transgenic lines were statistically significant as compared to untransformed parental control plants while the variation within transgenic lines was not significant (Table 1). Slight reduction in resistance against YSB was recorded at flowering stage as white heads observed during 2003, 2004 and 2005 were 2.42, 3.61 and $3.42 \%$ respectively as compared to white heads observed in untransformed control. Thus transgenic plants exhibited high levels of resistance against YSB at vegetative and flowering stage as compared to untransformed control.

Natural infestations of RLF were also observed during 2005 and all the transgenic lines were significantly resistant against RLF. The transgenic line L-8-22-2 showed 100\% resistance against RLF with no leaf damage while line L-822-32 and L-8-22-35 showed 98.83 and $98.67 \%$ resistance as only 1.17 and $1.33 \%$ of leaves were damaged as compared to untransformed control (Table 1). The resistance against lepidopteron insects was stably inherited during 2003-2005 and all plants showed high level of resistance against lepidopteran insects.

\section{Morphological and physiochemical characteristics}

Remarkable statistical differences were observed for average number of tillers among or between different transgenic lines and the untransformed control. During three years of field trials the transgenic lines showed an average number of tillers 24 as compared to 17 in control (Table 2). Average plant height of $108 \mathrm{~cm}$ was recorded for transgenic plants as compared to $156 \mathrm{~cm}$ in control (Table 2). Significant differences were observed when data were analyzed for the days required for panicle initiation and maturity. The transgenic plants were 25-27 days early in maturity when the data regarding panicle initiation and days to maturity were analyzed.

Panicle length is an important characteristic contributing significantly to grain yield. No statistical difference was observed for this character in transgenic lines (Table 2). The same results were observed in all three years of field trials. Flag leaf area showed non-significant variation when different lines were compared with each other and control. 
The presence or absence of awns is widely used to identify a variety or line and awns were absent on all transgenic lines while they were observed in untransformed control. Transgenic lines were superior to untransformed control during all years. Transgenic lines produced $40 \%$ more grains as compared to control (Table 2).

The variation with respect to grain length was within the range of 7.55-7.85 $\mathrm{mm}$. The average kernel length in the control was recorded as $7.40 \mathrm{~mm}$, which is comparable with the different transgenic lines. The average breadth ranged from 1.95 to $2.19 \mathrm{~mm}$ in different transgenic lines. It was found that all plants had ratio greater than 3.5 and fell in the category of long slender grains. The elongation ratio of the cooked seeds was also observed which was significantly different between transgenic lines. Bursting and curling are important parameters of cooked rice. The transgenic lines were significantly different for these characters (Table 3).

Average amylose contents were $23.67 \%$ for transgenic lines compared to $23.65 \%$ in the control. All the lines fall into intermediate amylose group according to the classification provided by INGER (1996). No variation was observed with respect to alkali spreading value, which ranged from 4-5 and gave a clue about the intermediate gelatinization temperature. Aroma was present in all transgenic lines as well as in the untransformed control (Table 3).

\section{Risk assessment studies}

No statistical difference was found for the germination of the three local varieties of wheat on filter paper moistened with extract of transgenic straw. The germination percentage for different varieties and under different treatments ranged between 96.3 and 99.3 for the control and transgenic plants respectively (Table 4). So, there is likely to be no allelopathic effect of transgenic rice on rotation crops such as wheat.

The presence of different non-target insects, predators and visiting insects (Table 5) was observed in the field and their activities were characterized. Transgenic plants did not have any effect on the survival of non-target insects. Throughout the field trial the damage was found 5.0, 6.1 and $6.3 \%$ in transgenic lines while 6.2, 5.1 and $6.4 \%$ respectively in control (Table 1 and Table 5). There was no significant difference in transgenic and untransformed control when leaf damage was compared.

Transgenic rice grains had no harmful effect on storage pests. Insect damaged transgenic grains as well as control with no significant difference. The damage in transgenic lines L-8-22-2, L-8-22-32 and L-8-22-35 showed 69.5, 86.5 and $105 \%$ respectively as compared to $100 \%$ damage in untransformed control plants (Table 1 and Table 5).

Twenty-one hybrids were identified in a population of 15,000 plants on the basis of leaf color with $0.14 \%$ out crossing. Fifteen hybrids were subjected to insect bioassays and ELISA. Fourteen out of 15 plants were positive in both tests. In F2 population segregation ratios were tested on media containing $50 \mathrm{mg} / \mathrm{ml}$ hygromycin, 12 hygromycin positive plants were randomly selected from progeny of a single hybrid and subjected to ELISA, 7 out of 12 proved positive for crylAc. Chi square test confirmed the Mendelian inheritance for crylAc. Artificial crosses were also attempted between L-8-22-2, L-8-22-32, CP1 and Basmati-370 in all combinations. F1 plants were grown and it was observed that all F1 plants of transgenic lines and Basmati-370 as well as transgenic lines and CP-1 were ELISA positive for $c r y l A c$. It was determined that $c r y l A c$ gene transferred in $58 \%$ of hybrid plants.

\section{DISCUSSION}

Transgenic rice expressing genes encoding insecticidal crystalline proteins from Bacillus thuringiensis could dramatically reduce the use of conventional broad-spectrum pesticides against insect pests. There is always a risk that insects could become resistant to $B t$ toxins after prolonged and repeated field exposure. The most practical approach to

Table 4. Allelopathic effects of transgenic rice on germination of three varieties of wheat.

\begin{tabular}{|l|c|c|c|}
\hline \multicolumn{1}{|c|}{ Treatments (Genes) } & Punjab, 96 & Uqab, 2000 & Iqbal, 2000 \\
\hline cry1Ac + cry2A & $99.00^{\mathrm{a}}$ & $97.70^{\mathrm{a}}$ & $98.00^{\mathrm{a}}$ \\
\hline cry1Ac & $99.30^{\mathrm{a}}$ & $98.00^{\mathrm{a}}$ & $99.00^{\mathrm{a}}$ \\
\hline cry2A & $98.70^{\mathrm{a}}$ & $97.00^{\mathrm{a}}$ & $97.70^{\mathrm{a}}$ \\
\hline Control & $96.30^{\mathrm{a}}$ & $99.00^{\mathrm{a}}$ & $97.30^{\mathrm{a}}$ \\
\hline
\end{tabular}

Note: Numbers with the same letter are not significantly different from each other according to LSD test at $5 \%$ level of significance. 
Table 5. Non-target insects of rice.

\begin{tabular}{|c|c|c|c|c|}
\hline S. No. & Common Name & Scientific Name & Family & Order \\
\hline \multicolumn{5}{|c|}{ Non-Target Insects of Rice } \\
\hline 1. & Rice Bug & Leptocorisa acuta (Thunberg) & Coreidae & Hemiptera \\
\hline 2. & Rice Thrips & Stenchaetothrips biformis Bagnall & Thripidae & Thysanoptera \\
\hline 3. & White-backed plant hopper & Sogatekka furcifera Horvath & Delphacidae & Homoptera \\
\hline 4. & Green leafhopper & Nephotellix cincticeps Ishihera & Deltocephalidae & Homoptera \\
\hline 5. & Brown Plant hopper & Nilapavata lugens Stal & Delpecidae & Homoptera \\
\hline 6. & White leafhopper & Cofana spectra (Dist.) & Cicadellidae & Homoptera \\
\hline 7. & Rice Grasshopper & Hieroglyphus banian Fb. & Acridae & Orthoptera \\
\hline 8. & Paddy Grasshopper & Oxya hyla (Serv.) & Acridae & Orthoptera \\
\hline 9. & Paddy Grasshopper & O. velox & Acridae & Orthoptera \\
\hline 10. & Rice Grasshopper & Atractomorpha crenulata F. & Acridae & Orthoptera \\
\hline 11. & Rice Grasshopper & Acrida exaltata Wlk. & Acridae & Orthoptera \\
\hline 12. & Rice Stink Bugs & Oebalus pugnax Fabricius. & Pentatomidae & Hemiptera \\
\hline \multicolumn{5}{|c|}{ Predators } \\
\hline 1. & Praying Mantid & Stagmomantis Carolina Johannson & Mantidae & Mantodea \\
\hline 2. & Dragon Fly & Sympetrum vulgatum & Aeshnidae & Odonata \\
\hline 3. & Damsen Fly & Coenagrion puella & Coenagrionidae & Odonata \\
\hline 4. & Spiders & Attacobius attarum & Corinnidae & Arachnida \\
\hline \multicolumn{5}{|c|}{ Storage Pests } \\
\hline 1. & Red Flour Beetle & Tribolium castaneum Herbst & Tenebrionidae & Coleoptera \\
\hline \multicolumn{5}{|c|}{ Visiting Insects } \\
\hline 1. & Red Pumpkin Beetle & Aulacophora foveicollis Lucas & Chrysomelidae & Coleoptera \\
\hline 2. & Sugarcane Pyrilla & Pyrilla perpusilla Walk. & Lophopidae & Hemiptera \\
\hline
\end{tabular}

prolong the effectiveness of $B t$ crops was a high dose/refugia strategy and pyramiding of two or more genes in the same cultivar (Cohen et al. 2000). Here we review the performance of different locally transformed lines of basmati rice against devastating insects during 2003-2005. The response of transgenic lines to non-target insects, chances of pollen mediated gene flow, morphological and physiological variation in transgenic plants and lessons learned through six years of field trials are also discussed.

Different transgenic lines provided up to $100 \%$ and $96 \%$ additional resistance against $\mathrm{YSB}$ at vegetative and flowering stage respectively while $98 \%$ additional resistance against RLF. Although white heads were observed in all transgenic lines expressing the two $B t$ genes but we failed to recover any live larvae from stem cutting rather all the larvae recovered were dead showing typical 
symptoms of $B t$ toxicity (Bashir et al. 2005). These lines provided built-in resistance against target insects at all stages of plant growth. Up to $8^{\text {th }}$ generation and after five years of field exposure, it was observed that resistance against insects was very stable during all years.

Resistance to different lepidopteron insects has been reported in Japonica and Indica rice expressing $B t$ toxins (Ye et al. 2001a; Ye et al. 2001b; Ye et al. 2003; Bashir et al. 2004a; Breitler et al. 2004; Bashir et al. 2005), and one report described resistance against eight lepidopteran insects through expression of the $c r y l A b$ gene (Shu et al. 2000). Present results showed that lines expressing two $B t$ genes are not only important for resistance management but also provided high level of protection against economically important lepidopteran insects.

Recently, Zhau et al. (2003) reported results from a green house study that pyramiding two toxin genes with different modes of action into plants offers a means of achieving longer delays in the development of resistance and mostly fit the predictions of simple genetic simulation models. Toxin titer differs substantially among plant lines that are transformed with the same $B t$ gene construct (Cheng et al. 1998; Datta et al. 1998) and declines substantially at reproductive stages in rice (Alinia et al. 2000). The selection of lines expressing high dose titer is extremely important. These lines expressed high levels of $B t$ protein during all stages of plant growth (Bashir et al. 2005)

Lines harbouring two $B t$ genes were superior as compared to untransformed control with respect to the average no. of tillers, average plant height, days to flowering as well as lodging incidence. Lines L-8-22-2, L-8-22-32 and L-8-2235 had a $36-37 \%$ reduction in plant height and this characteristic was stably inherited up to $8^{\text {th }}$ generation as data recorded in field were in line with data recorded in 2001-2002 (Bashir et al. 2005). Reduction in plant height also contributed significantly to resistance to lodging in these lines. Short plants are desirable from the breeding point of view and several reports indicated that transformation inherently reduced plant height (Jiang et al. 2000). Lines L-8-22-2, L-8-22-32 and L-8-22-35 were up to 25 days earlier in flowering.

It is already documented that transgenic lines may be early or late in maturity (Jiang et al. 2000). Possible reasons for this morphological variation may be somaclonal variation (Larkin and Scowcroft, 1981), breakdown of plant genes caused by transgene insertion or insertion mutagenesis (Van Lijsebettens et al. 1991), pleiotropy or transgene induced endogenous silencing (Matzke et al. 2000). Somaclonal variation seems the most likely cause of these changes as it took more time to produce transgenic plants as compared to normal tissue culture procedure and the longer the tissue culture time the higher the frequency of somaclonal variation (Kaeppler et al. 2000). Antibodies like hygromycin in this case might also induce mutations in rice (Wu et al. 2000).
No significant variation was observed for the characteristics like panicle length and flag leaf area. It was also concluded that the most affected characteristics were the average number of tillers, plant height and maturity and other characteristics were comparable with control. The yield of all transgenic lines was significantly superior to the control.

In short, transgenic basmati lines expressing two unrelated $B t$ genes, cry $1 A c$ and $c r y 2 A$ provided protection against lepidopteran insects throughout the growth period. Three homozygous lines (L-8-22-2, L-8-22-32 and L-8-22-35) derived from a single line provided high resistance against lepidopteran insects till harvesting and were desirable in morphological characteristic. Most importantly these lines showed resistance up to advanced generations and we did not observe gene silencing or segregation for cry genes. Although these lines were significantly different from untransformed control for plant height, days to maturity. These characteristics were stably inherited till $8^{\text {th }}$ generation and we did not observe any abnormality or segregation associated with these lines.

Only 5\% of rice grown is used as processed food and humans consume $95 \%$ as unprocessed food, which increases the importance of its physiochemical properties. Grains were long and slender with average length between 7.55 to $7.85 \mathrm{~mm}$. variation with respect to apparent amylose content was not significant as all the lines fall in the category of intermediate amylose content (between 23-25\% apparent amylose; IRRI, 1972). Little variation may result from environment, as amylose contents vary among panicles and plants. Variation of alkali spreading value was negligible.

The response of all transgenic lines to cooking, i.e., curling and bursting percentage, elongation ratio and stickiness also varied among all lines. Aroma was present in all transgenic lines as well as in control plants. Small variation with respect to different physiochemical properties among lines may be correlated with the environment. Although all lines were sown in a similar environment and at the same time, these lines significantly differ in terms of the days required for maturity. Thus different lines experienced different temperatures at the grain ripening stage, which slightly changed their physiochemical properties (Stansel et al. 1965). Therefore it was observed that transformation does not alter the physiochemical properties of rice.

\section{Risk assessment studies}

Allelopathic effects of transgenic rice on germination of wheat are extremely important in an ecosystem with wheat rice rotation. No difference was observed in the effects of transgenic lines on the germination of wheat. Results suggest that $B t$ rice is safe for non-target insects, storage pests and visiting insects and has no effect on the germination of wheat. The chances of pollen-mediated gene flow from transgenic lines to their untransformed 
counterparts through natural cross-pollination are also very low $(0.14 \%)$.

The specificity of cry genes for particular orders of insects is their most significant attribute. Bt sprays do not disturb the overall buildup of predator or parasitoid communities or population trajectories of non-target herbivores (Plant hoppers and leafhoppers; Schoenly et al. 2003). A common method to check the response of transgenic lines to such insects is to compare the number of non-target insects on the transgenic lines and controls (Fitt et al. 1994; Sims, 1995; Orr and Landis, 1997; Bashir et al. 2004a; Bashir et al. 2004b). Results from the present study suggest that $B t$ rice is safe for non-target insects, storage pests and visiting insects.

\section{CONCLUDING REMARKS}

Our group has been engaged in field trials of $B t$ rice since 2000 and so far we have evaluated 16 different transgenic lines expressing one $($ crylAc or $c r y 2 A)$, two $($ crylAc + $\operatorname{cry} 2 A)$ and three genes (crylAc + cry $2 A+$ gna). Transgenic lines (L-8-22-2, L-8-22-32 and L-8-22-35) showed highest level of resistance against lepidopteran insects among all lines we have tested so far. Transgenic rice is a source of efficient control against most damaging insect pests of rice crop. The transgenic plants are more than $96 \%$ resistant against YSB and RLF. These lines also showed better agronomic and morphological characteristics as compared to control, i.e. plant height, number of tillers, days to maturity, grain length, yield, etc. These lines showed no harmful effects on non-target beneficial insects and no allelopathic effects on germination of wheat. The chances of pollen-mediated gene flow from transgenic lines to non-transformed plants were negligible. On the basis of data presented to date, these lines seem suitable candidate to be released as the first Indica basmati rice expressing two $B t$ genes.

\section{ACKNOWLEDGMENTS}

The authors are thankful to Dr. Saeed Akhtar, ExChairman, Department of Zoology, University of the Punjab, Lahore, Pakistan for his technical help in identification of insects collected from field.

\section{REFERENCES}

ALINIA， F.; GHAREYAZIE， B.; RUBIA， L.G.; BENNETT, J. and COHEN, M.B. Effect of plant age, larval age, and fertilizer treatment on resistance of a $c r y l A b$ - transformed aromatic rice to lepidopterous stem borers and foliage feeders. Journal of Economic Entomology, April 2000, vol. 93, no. 2, p. 484-493.

ANDREWS, R.W.; FAUSR, R.; WABIKO, M.H.; ROYMOND, K.C. and BULLA, L.A. Biotechnology of Bt: A critical review. Bio/Technology, 1987, vol. 6, p. 163-232.
BASHIR, Khurram; HUSNAIN, Tayyab and RIAZUDDIN, Sheikh. Response of transgenic rice expressing two $B t$ genes to nontarget insects. International Rice Research Notes, December 2004b, vol. 29, no. 2, p. 15-16.

BASHIR, Khurram; HUSNAIN, Tayyab; FATIMA, Tahira; LATIF, Zakia; MEHDI, Syed Aks and RIAZUDDIN, Sheikh. Field evaluation and risk assessment of transgenic indica basmati rice. Molecular Breeding, May 2004a, vol. 13 , no. 4 , p. 301-312.

BASHIR, Khurram; HUSNAIN, Tayyab; FATIMA, Tahira; RIAZ, Naveeda; MAKHDOOM, Rahat and RIAZUDDIN, Sheikh. Novel indica basmati line (B-370) expressing two unrelated genes of Bacillus Thuringiensis is highly resistant to two lepidopteran insects in the field. Crop Protection, October 2005, vol. 24, no. 10, p. 870-879.

BOARD ON AGRICULTURE AND NATURAL RESOURCES (BANR). Genetically modified pestprotected plants: science and regulation. Washington D.C., USA, National Academy Press, 2000. 292 p. ISBN 0-30906930-0. Available from Internet: http://fermat.nap.edu/books/0309069300/html.

BREITLER, Jean Christophe; VASSAL, Jean Michel; CATALA, Maria del Carmen; MEYNARD, Donaldo; MARFA, Victoria; MELÉ, Eric; ROYER, Monique; MURILLO, Isabel; SAN SEGUNDO, Blanca; GUIDERDONI, Emmanuel and MESSEGUER, Joaquina. $B t$ rice harbouring cry genes controlled by a constitutive or wound-inducible promoter: protection and transgene expression under Mediterranean field conditions. Plant Biotechnology Journal, September 2004, vol. 2, no. 5, p. 417-430.

CHENG, Xiongying; SARDANA, Ravinder; KAPLAN, Harvey and ALTOSAAR, Illimar. Agrobacteriumtransformed rice plants expressing synthetic $\operatorname{cryl} A(b)$ and $\operatorname{cryl} A(c)$ genes are highly toxic to striped stem borer and yellow stem borer. Proceedings of the National Academy of Sciences of the United States of America, March 1998, vol. 95 , no. 6, p. 2767-2772.

COHEN, B.M.; GOULD, F. and BENTUR, J.C. Bt rice: practical steps to sustainable use. International Rice Research Notes, 2000, vol. 25, no. 2, p. 4-10.

DATTA, K.; VASQUEZ, A.; TU, J.; TORRIZO, L.; ALAM, M.F.; OLIVA, N.; ABRIGO, E.; KHUSH, G.S. and DATTA, S.K. Constitutive and tissue-specific differential expression of the crylA(b) gene in transgenic rice plants conferring resistance to rice insect pests. Theoretical and Applied Genetics, July 1998, vol. 97, no. 12, p. 20-30.

DHALIWAL, Harcharan S.; KAWAI, Maki and UCHIMIYA, Hirofumi. Genetic engineering for abiotic stress tolerance in plants. Plant Biotechnology, 1998, vol. 15 , no. 1, p. 1-10. 
DONG, Y.J.; SUZUKI, E.T. and TERAO, H. Inheritance of aroma in four rice cultivars (Oryza sativa L.). International Rice Research Notes, August 2000, vol. 25, no. 2, p. 15.

FERRÉ, Juan and VAN RIE, Jeroen. Biochemistry and genetics of insect resistance to Bacillus thuringiensis. Annual Review of Entomology, January 2002, vol. 47, p. 501-533.

FITT, G.P.; MARES, C.L. and LLEWELLYN, D.J. Field evaluation and potential ecological impact of transgenic cotton (Gossypium hirsutum) in Australia. Biocontrol Science and Technology, 1994, vol. 4, p. 535-548.

FIUZA， L.M.; NIELSEN-LEROUX, C.; GOZÈ, E.; FRUTOS, R. and CHARLES, J.F. Binding of Bacillus thuringiensis Cry1 toxins to the midgut brush border membrane vesicles of Chilo suppressalis (Lepidoptera: Pyralidae): evidence of shared binding sites. Applied and Environmental Microbiology, May 1996, vol. 62, no. 5, p. 1544-1549.

Food and Agriculture Organization of the United Nations (FAO). FAO Quarterly Bulletin of Statistics, 1995, vol. 8, no. 1-2.

Food and Agriculture Organization of the United Nations (FAO). The state of food security in the world, 2004, p. 3031.

FRUTOS, Roger; RANG, Cécile and ROYER, Monique. Managing insect resistance to plants producing Bacillus thuringiensis toxins. Critical Reviews in Biotechnology, September 1999, vol. 19, no. 3, p. 227-276.

HERRNSTADT, Corinna; SOARES, George G.; WILCOX, Edward R. and EDWARDS, David L. A new strain of Bacillus thuringiensis with activity against coleopteran insects. Bio/Technology, April 1986, vol. 4, no. 4, p. 305-308.

HÖFTE, H. and WHITELEY, H.R. Insecticidal crystal proteins of Bacillus thuringiensis. Microbiological Reviews, June 1989, vol. 53, no. 2, p. 242-255.

HUESING, Joseph and ENGLISH, Leigh. The impact of $B t$ crops on the developing world. AgBioForum, 2004, vol. 7, no.1-2, p. 84-95.

HUSNAIN, Tayyab; KHANUM, F.; RIAZUDDIN, Sheikh and GORDON, Milton P. Transformation of Basmati rice (Oryza sativa L.) with bacterial genes by particle bombardment. Pakistan Journal of Plant Science, 1995, vol. 1, p. 219-228.

HUSNAIN, Tayyab; MALIK, Tahira; RIAZUDDIN, Sheikh and GORDON, Milton P. Studies on the expression of marker genes in chickpea. Plant Cell, Tissue and Organ Culture, April 1997, vol. 49, no. 1, p. 7-16.
International Rice Research Institute (IRRI). Annual report for 1971. Los Banos, Philippines, 1972. 238 p.

JIANG, Junda; LINSCOMBE, Steve D.; WANG, Jianlin and OARD, James H. Field evaluation of transgenic rice (Oryza sativa L.) produced by Agrobacterium and particle bombardment methods. In: Plant and Animal Genome VIII Conference $\left(9^{\text {th }}-12^{\text {th }}\right.$ January, 2000, San Diego, CA, USA). Available from Internet: http://www.intlpag.org/8/abstracts/pag8695.html.

JULIANO, B.O. A simplified assay for milled rice amylose. Cereal Science Today, 1971, vol. 16, p. 334-338.

KAEPPLER, Shawn M.; KAEPPLER, Heidi F. and RHEE, Yong. Epigenetic aspects of somaclonal variation in plants. Plant Molecular Biology, June 2000, vol. 43, no. 2-3, p. 179-188.

KHAN, Z.R.; LITSINGER, J.A.; BARRION, A.T.; VILLANUEVA, F.F.D.; FERNÁNDEZ, N.J. and TAYLOR, L.D. World bibliography of rice stem borers 1794-1990. International Rice Research Institute, Los Banos, Philippines, 1991. 415 p. ISBN 971-22-0015-9.

KHUSH, G.S. and BRAR, D.S. Biotechnology for rice breeding: Progress and Potential impact. In: Proceeding of the 20th Session of the International Rice Commission ( $23^{\text {rd }}$ $-26^{\text {th }}$ July, 2002, Bangkok, Thailand). Available from Internet:

http://www.fao.org/docrep/006/Y4751E/y4751e04.htm.

KRIEG, A.; HUGER, A.M.; LANGENBRUCH, G.A. and SCHNETTER, W. Bacillus thuringiensis var tenebrionis: a new pathotype effective against larvae of coleopteran. Journal of Applied Entomology, 1983, vol. 96, p. 500-508.

LARKIN, P.J. and SCOWCROFT, W.R. Somaclonal variation - a novel source of variability from cell cultures for plant improvement. Theoretical and Applied Genetics, October 1981, vol. 60, no. 4, p. 197-214.

LITTLE, R.R.; HILDER, G.B. and DAWSON, E.H. Differential effect of dilute alkali on 25 varieties of milled white rice. Cereal Chemistry, 1958, vol. 35, p. 111-126.

LYCETT, G.W. and GRIERSON, D. Genetic engineering of crop plants. Butterworth-Heinemann, London, UK, 1990. 303 p. ISBN 0-40-804779-8.

MAHALINGAM, L. and NADARAJAN, N. Inheritance of purple pigmentation in two-line rice hybrids. International Rice Research Notes, June 2005, vol. 30, no. 1, p. 12.

MATZKE, M.A.; METTE, M.F. and MATZKE, A.J.M. Transgene silencing by the host genome defense: implications for the evolution of epigenetic control mechanisms in plants and vertebrates. Plant Molecular Biology, June 2000, vol. 43, no. 2-3, p. 401-415. 
National Biosafety Committee (NBC). Biosafety guidelines in genetic engineering and biotechnology. Ministry of Environment Local Government, Rural Development, Government of Pakistan, 1999.

ORR, D.B. and LANDIS, D.A. Oviposition of Eauropean corn borer (Lepidoptera: pyralidae) and impact of natural enemy populations in transgenic versus isogenic corn. Journal of Economic Entomology, August 1997, vol. 90, no. 4, p. 905-909.

SALIM, M. and MASIH, R. Efficacy of insecticides against rice stem borer at NARC, Islamabad. Pakistan Journal of Agricultural Research, 1987, vol. 8, no. 4, p. 477-479.

SCHOENLY, Kenneth G.; COHEN, Michael B.; BARRION, Alberto T.; ZHANG, Wenjun; GAOLACH, Bradley and VIAJANTE, Vicente D. Effects of Bacillus Thuringiensis on non-target herbivore and natural enemy assemblages in tropical irrigated rice. Environmental Biosafety Research, July-September 2003, vol. 2, no. 3, p. 181-206.

SHU, Qing-Yao; YE, Gong-Yin; CUI, Hairui; CHENG, Xiong-Ying; XIANG, Youbin; WU, Dianxing; GAO, Mingwei; XIA, Ying-Wu; HU, Cui; SARDANA, Ravinder and ALTOSAAR, Illimar. Transgenic rice plants with a synthetic crylAb gene from Bacillus thuringiensis were highly resistant to eight lepidopteran rice pest species. Molecular Breeding, August 2000, vol. 6, no. 4, p. 433439.

SIMS, S.R. Bacillus thuringiensis var kurstaki (Cry1Ac) protein expressed in transgenic cotton: effects on beneficial and other non-target insects. Southwestern Entomologist, December 1995, vol. 20, no. 4, p. 493-500.

STANSEL, J.W.; BOLLICH, C.N.; THYSELL, J.R. and HALL, V.L. The influence of light intensity and nitrogen fertility on rice yields and components of yield. Rice Journal, 1965, vol. 68, no. 4, p. 34-35, 49.

The International Network for Genetic Evaluation of Rice (INGER). Standard evaluation system for rice. $4^{\text {nd }}$ ed. International Rice Research Institute, Los Banos, Philippines, 1996.63 p.

VAN LIJSEBETTENS, M.; VANDERHAEGHEN, R. and VAN MONTAGU, M. Insertional mutagenesis in Arabidopsis thaliana: Isolation of a T-DNA-linked mutation that alters leaf morphology. Theoretical and Applied Genetics, February 1991, vol. 81, no. 2, p. $277-$ 284.

WHITELEY, H.R. and SCHNEPF, H.E. The molecular biology of parasporal crystal body formation in Bacillus thuringiensis. Annual Review of Microbiology, October 1986, vol. 40, p. 549-576.
WILLIAMS, Virginia R.; WU, Wei-Ting; TSAI, Hsiu Y. and BATES, Harold G. Varietal difference in amylose contents of rice starch. Journal of Agricultural and Food Chemistry, January 1958, vol. 6, no. 1, p. 47-48.

WU, G.; CUI, H.R.; SHU, Q.; XIA, Y.W.; XIANG, Y.B.; GAO, M.W.; CHENG, X. and ALTOSAAR, I. Stripped stem borer (Chilo suppressalis) resistant transgenic rice with a crylAb gene from Bt (Bacillus thuringiensis) and its rapid screening. Journal of Zhejiang University, 2000, vol. 19 , no. 3, p. 15-18.

YE, Gong-Yin; SHU, Qing-Yao; YAO, Hong-Wei; CUI, Hai-Riu; CHENG, Xiong-Ying; HU, Cui; XIA, Yin-Wu; GAO, Ming-Wei and ALTOSAAR, I. Field evaluation of resistance of transgenic rice containing a synthetic cryl $\mathrm{Ab}$ gene from Bacillus thuringiensis berliner to two stem borers. Journal of Economic Entomology, February 2001a, vol. 94, no. 1, p. 271-276.

YE, G.-Y.; TU, J.; DATTA, K. and DATTA, S.K. Transgenic IR72 with fused $B t$ gene crylAb/crylAc from Bacillus thuringiensis is resistant against four lepidopteran species under field conditions. Plant Biotechnology, 2001b, vol. 18, no. 2, p. 125-133.

YE, Guang-Ning; COLBURN, Susan M.; XU, Charles W.; HAJDUKIEWICZ, Peter T.J. and STAUB, Jeffrey M. Persistence of unselected transgenic DNA during a plastid transformation and segregation approach to herbicide resistance. Plant Physiology, September 2003, vol. 133, no. 1, p. 402-410.

ZHAU, Jian-Zhou; CAO, Jun; LI, Yaxin; COLLINS, Hilda L.; ROUSH, Richard T.; EARLE, Elizabeth D. and SHELTON, Anthony M. Transgenic plants expressing two Bacillus thuringiensis toxins delay insect resistance evolution. Nature Biotechnology, December 2003, vol. 21, no. 12 , p. 1493-1497. 